\title{
COVID-19-related knowledge, attitudes, and practices among decisionmakers of indigenous municipalities in Guatemala: Study description
}

Angel del Valle

Population Council

Hannah Briggs

Benjamin Chang

Aiken Chew

Brian Medina

Population Council

See next page for additional authors

Follow this and additional works at: https://knowledgecommons.popcouncil.org/departments_sbsr-pgy

Part of the Demography, Population, and Ecology Commons, International Public Health Commons, and the Public Health Education and Promotion Commons How does access to this work benefit you? Let us know!

\section{Recommended Citation}

del Valle, Angel, Hannah Briggs, Benjamin Chang, Aiken Chew, Brian Medina, Gabriela Muñoz, Thoai Ngo, Elizabeth Vásquez, Corinne White, and Ramón Zamora. 2020. "COVID-19-related knowledge, attitudes, and practices among decisionmakers of indigenous municipalities in Guatemala: Study description."

Guatemala City: Population Council. 


\section{Authors}

Angel del Valle, Hannah Briggs, Benjamin Chang, Aiken Chew, Brian Medina, Gabriela Muñoz, Thoai Ngo, Elizabeth Vásquez, Corinne White, and Ramón Zamora 
COVID-19-related knowledge, attitudes, and practices among decisionmakers of indigenous municipalities in Guatemala ${ }^{1}$

Study Description

April 17, 2020

Authors: Angel del Valle ${ }^{1}$, Hannah Briggs ${ }^{2}$, Benjamin Chang ${ }^{3}$, Aiken Chew ${ }^{3}$, Brian Medina ${ }^{1}$, Gabriela Muñoz ${ }^{1}$, Thoai D. Ngo ${ }^{4}$, Elizabeth Vásquez ${ }^{1}$, Corinne White ${ }^{4}$, Ramón Zamora ${ }^{3}$

\section{Affiliations:}

1. Population Council, Guatemala City, Guatemala

2. Columbia University, Mailman School of Public Health, New York, NY

3. Universidad del Valle de Guatemala, Guatemala City, Guatemala

4. Poverty, Gender, and Youth Program, Population Council, New York, NY

\section{Corresponding authors:}

Angel del Valle, MA

Country Representative, Guatemala

+50223690292

adelvalle@popcouncil.org

Thoai D. Ngo, PhD, MHS

Director, Poverty, Gender, and Youth Program

+1 212 339-0500

tngo@popcouncil.org

\section{POPULATION COUNCIL}

IDEAS. EVIDENCE. IMPACT.

One Dag Hammarskjold Plaza

New York, NY 10017

www.popcouncil.org

\footnotetext{
${ }^{1}$ This document is evolving due to the nature of the COVID-19 response and will be updated as needed.
} 


\begin{abstract}
:
Indigenous communities are often socially and economically marginalized which makes them particularly vulnerable to the impact of COVID-19. The Population Council has a longstanding partnership with indigenous communities in Guatemala through the Abriendo Oportunidades (AO) program. To understand the knowledge, perspectives, and needs related to the COVID-19 pandemic, we will conduct key informant interviews with indigenous community leaders and frontline workers. Phonebased surveys will be carried out with approximately 130 key informants in the municipalities of Chisec, Patzún, San Andrés Semetabaj, San Juan Ostuncalco, San Juan Sacatepéquez, San Pedro Carchá, Santa María Chiquimula, Totonicapán, Uspantán and Sololá in April 2020. These individual profiles will include heads of household, former girl-program mentors, community health workers and providers, education officers, traditional birth attendants, and municipal officers. We anticipate this effort will provide initial baseline information and subsequent interviews may be conducted throughout 2020. Results from this study will help inform national and municipal prevention and mitigation strategies for indigenous communities and identify government resources that may be prioritized to meet the needs of these communities. Findings will also help decisionmakers understand the effects that COVID-19 is having on girls, girls' education, and sexual and reproductive health under these rapidly changing conditions. We will follow the data collection standards as established in the Population Council Institutional Review Board guidelines, adjusted in light of COVID-19. We are committed to openly sharing the latest versions of the study description, questionnaires, datasets, and preliminary results.
\end{abstract}

\title{
I. Background
}

As of April 2020, Guatemala currently has close to 200 cases of COVID-19, ("Johns Hopkins Coronavirus Resource Center," 2020). The risk to spreading coronavirus is due in large part to travel from countries with higher rates of COVID-19. Global health experts and Latin American governments have expressed concern about the spread of COVID-19 and potential for more than 3.1 million deaths in Latin America and the Caribbean if no action is taken (Walker et al, 2020).

Across world regions, indigenous populations are at higher risk during epidemics as they often lack access to healthcare and essential services, including sanitation and other key prevention methods, and face higher rates of communicable and non-communicable diseases (United Nations, 2020). In Guatemala, where about $40 \%$ of the population is indigenous, studies have documented the disadvantages faced by the indigenous population in utilizing the public healthcare system, including language barriers and verbal abuse (Cerón et al, 2016). Data from indigenous populations in Brazil during viral respiratory infection outbreaks point to this disparity. During the 2009 H1N1 outbreaks, death rates among indigenous populations were substantially higher, and during a 2016 influenza even with a high vaccination rate in an indigenous community, there were no differences in vaccination rates among severe and non-severe cases (La Ruche et al, 2009; Cardoso et al, 2019). Fragile health systems will exacerbate the impact of the outbreak and limit the ability to conduct adequate surveillance and control (Makoni, 2020). Anecdotal experiences reported by indigenous leaders in Guatemala point to the risk of individuals and families with symptoms opposing to quarantines measures, limited capacity of the local health system to respond to overcrowded clinics, lack of accurate information available in local 
languages and pressure on livelihoods that depend on agricultural practices due to the restrictions on mobility (Anona, 2020).

Without sustained bans on large gatherings (including specific cultural and faith practices such as mass prayer gatherings, large weddings and funerals) these may create super-spreading events that accelerate transmission (Wong et al, 2015). This situation is compounded by the spread of COVID-19 misinformation including unsupported treatments or promotion of ineffective preventive behaviors (Ioannidis, 2020; Vigdor, 2020). To prevent the devasting health, social and economic impact of a COVID19 outbreak, containment is an important first step and extensive mitigation efforts will be required. As of April 10, the government declared a State of Calamity that includes the suspension of inessential activities of the in the private and public sectors, closing of all national borders, suspension of public means of transportation, a curfew (4 p.m. until 4 a.m.) and limited inter-municipal travel (IMF, 2020). Indigenous municipalities have adopted such measures but are facing challenges in regulating local markets and small businesses, due to their central role in an economic system that is largely informal and depends on agricultural practices (Coronado, 2020). In order for these efforts to be effective, health authorities will need timely and actionable data to design policies and interventions that are easily understood and relevant to the lives of indigenous communities.

The Office for the Defense of Indigenous Women (Defensoría de la Mujer Indígena) is collaborating with the Population Council-Guatemala to rapidly gather information on the knowledge, attitudes, and practices of municipal decision-makers in ten indigenous municipalities in a series of phone-based surveys. This will inform the development and planning of behavior change campaigns, COVID-19 tracking, and other interventions as needed throughout the pandemic.

\section{Research Question}

Collecting knowledge, perceptions, and needs among at-risk populations is useful to inform prevention, control and mitigation measures during epidemics. A recent example is from the Ebola response in 2015-2016, during which such information helped identified the prevalence of misconceptions about Ebola transmission and prevention, the need to prevent stigmatization of Ebola survivors, and to foster safer case management and burial practices (Jalloh et al, 2017). Information from these types of survey is pivotal for policymakers and program implementers to use not only during the outbreak but also during the recovery stages. We are undertaking a series of key informant interviews among decisionmakers, community members, and frontline responders in indigenous municipalities to answer the following questions:

1. What is the current knowledge, attitudes, and practices reported by the community members related to COVID-19? How do these change over time?

2. What are the main barriers to adoption of key behaviors for COVID-19 prevention (e.g., handwashing, social isolation)?

3. What behavior change messages are the most effective at increasing knowledge related to COVID-19 prevention?

4. What are the collective concerns and needs experienced by indigenous communities? 


\section{Research Design}

This study will deploy rapid phone-based key informant interviews of indigenous municipal decisionmakers, including female heads of households, former girl-program mentors, community leaders, community health workers, health providers, education officers, municipal officers, and traditional birth attendants sampled from communities with deep ties to the ongoing Population Council Abriendo Oportunidades program $(n=130)$. Iterations of the survey may be conducted every two weeks to one month, beginning in April 2020. Each survey will last 25-30 minutes and be conducted on the phone with a research assistant. Baseline findings on awareness of COVID-19 symptoms, perceived risk, awareness of and ability to carry out preventive behaviors, misconceptions, and fears will inform national and municipal resources that should be prioritized to respond to the COVID-19 pandemic in indigenous settings.

Future surveys can assess how the specific mitigation measures, and duration of these measures, impact a range of indicators including health, mental health and wellbeing, educational attainment and literacy, and economic status. For example, data may be analyzed to understand how social distancing measures influence consumption patterns and the impacts on income in these communities.

\section{Target population}

Leveraging Abriendo Oportunidades, a mentor-run, girl-centered program that has been implemented by the Population Council and partners in indigenous communities since 2004, 130 key informant interviews will be conducted across 10 rural municipalities. Per community the sample will include the following profiles: 3 former Abriendo Oportunidades mentors, 3 female heads of household, 2 community leaders, 1 community health worker, 1 health provider from the local health clinic, 1 education officer from the local school, 1 municipal-level officer, and 1 traditional birth attendant. These communities are largely indigenous. This group of individuals will be re-contacted in future survey rounds and studies.

\section{Survey instrument}

The first survey will serve as a baseline, asking participants about their awareness of COVID-19, perceived risk of infection, identification of high risk groups, awareness of promoted behaviors, misconceptions regarding treatment and disease spread, and will ask questions about channels through which they receive information, trust in those sources, and perceived ability to carry out preventive behaviors by themselves and their community. Subsequent rounds of data collection will ask some of the same questions to see how knowledge, attitudes and practices change over time, and may include additional modules related to exposure to behavior change messaging, responses to these campaigns, and perspectives on the government's response efforts.

\section{Limitations}

During the COVID-19 outbreak, it will not be possible to collect data or conduct behavior change campaigns in person, to protect health workers and field-based staff. We will conduct additional rounds 
of rapid surveys to assess exposure to and awareness of government messaging campaigns (and campaigns run by other public health partners) and track how the needs of these communities change over time. Because this is a key informant survey that aim to understand collective needs of these communities, we will not be able to disaggregate information by household or individual.

\section{Contribution to Response}

\section{Partnership with Office for the Defense of Indigenous Women}

The Population Council-Guatemala is partnering with the Office for the Defense of Indigenous Women (Defensoría de la Mujer Indígena) in Guatemala is developing a COVID-19 response that is sensitive to the worldviews of indigenous communities, especially that of women and that considers girls. Due to the limited capacity of the national government to collect data on knowledge, attitudes and practices in rural communities, this effort will provide actionable data in near real-time as the pandemic evolves. The Council will ensure our work is accessible and useful for local and municipal government planning.

\section{Gender lens}

Women and girls are highly vulnerable during an epidemic or crisis, it is critical to disaggregate by gender in all of our analyses. In many settings, women and girls are at increased risk during an epidemic because they are responsible not only for caring for the elderly and children, but because they often make up more than half of the healthcare workforce (Wenham et al, 2020). Financial opportunities and access to resources, information, and support will be severely affected as schools and businesses close and social distancing measures are put in place. Sexual and gender-based violence is already very prevalent in these communities. In humanitarian emergencies and noted in China after its COVID-19 lockdown, the risk of gender-based violence increases (Wanqing, 2020).

\section{Open access}

We are committed to openly sharing the latest version of this study description, questionnaires, datasets, and preliminary results. Please visit the Population Council COVID-19 Research \& Evaluations page on Dataverse regularly for updates.

\section{References}

Anona, Jhonny (2020, March 29). Transporte público en Sumpango: Las restricciones siguen, la necesidad también. Plaza Pública. https://www.plazapublica.com.gt/content/transporte-publico-en-sumpango-lasrestricciones-siguen-la-necesidad-tambien

Cardoso, A.M., Resende, P.C., ... Siqueira, M.M. et al. (2019). Investigation of an outbreak of acute respiratory disease in an indigenous village in Brazil: Contribution of Influenza A(H1N1)pdm09 and human respiratory syncytial viruses. PLoS ONE 14(7): e0218925.

https://doi.org/10.1371/journal.pone.0218925 


\section{POPULATION}

COUNCIL

Ideas. Evidence. Impact.

Cerón, A., Ruano, A.L., Sánchez, S., Chew, A.S., Díaz, D., Hernández, A., \& Flores, W. (2016). Abuse and discrimination towards indigenous people in public health care facilities: experiences from rural Guatemala. International Journal for Equity in Health 15: 77. https://doi.org/10.1186/s12939-016-0367$\underline{z}$

Dahab, M., van Zandvoort, K., Flasche, S., Warsame, A., Spiegel, P. B., Waldman, J., \& Checchi, F. (2020, March 20). COVID-19 control in low-income settings and displaced populations: What can realistically be done? https://www.Ishtm.ac.uk/newsevents/news/2020/covid-19-control-low-income-settings-anddisplaced-populations-what-can

International Monetary Fund (2020). Policy Responses to COVID-19. https://www.imf.org/en/Topics/imfand-covid19/Policy-Responses-to-COVID-19\#G

Ioannidis, J. P. A. (2020). Coronavirus disease 2019: The harms of exaggerated information and nonevidence-based measures. European Journal of Clinical Investigation, n/a(n/a), e13223.

https://doi.org/10.1111/eci.13223

Jalloh, M. F. (2017). Knowledge, Attitudes, and Practices Related to Ebola Virus Disease at the End of a National Epidemic-Guinea, August 2015. MMWR. Morbidity and Mortality Weekly Report, 66.

https://doi.org/10.15585/mmwr.mm6641a4

Johns Hopkins Coronavirus Resource Center. (2020). Johns Hopkins Coronavirus Resource Center. https://coronavirus.jhu.edu/

La Ruche, G., Tarantola, A., Barboza, P., Vaillant, L., Gueguen, J., Gastellu-Etchegorry, M., \& for the epidemic intelligence team at InVS. (2009). The 2009 pandemic of H1N1 influenza and indigenous populations of the Americas and the Pacific. Eurosurveillance 14(42): 51-56.

https://doi.org/10.2807/ese.14.42.19366-en

Makoni, M. (2020). Africa prepares for coronavirus. The Lancet, 395(10223), 483.

https://doi.org/10.1016/S0140-6736(20)30355-X

Coronado, Elsa. (2020, March 16). San Pedro Sacatepéquez, el foco del COVID-19. Plaza Pública.

Retrieved from: https://www.plazapublica.com.gt/content/san-pedro-sacatepequez-el-foco-del-covid19

Vigdor, N. (2020, March 24). Man Fatally Poisons Himself While Self-Medicating for Coronavirus, Doctor Says. The New York Times. https://www.nytimes.com/2020/03/24/us/chloroquine-poisoning-

coronavirus.html

United Nations. (2020). COVID-19 and Indigenous peoples.

https://www.un.org/development/desa/indigenouspeoples/covid-19.html

Walker, P., Whittaker C., Watser, O., et al (2020). The Global Impact of COVID-19 and Strategies for Mitigation and Suppression. WHO Collaborating Centre for Infectious Disease Modelling, MRC Centre for Global Infectious Disease Analysis, Abdul Latif Jameel Institute for Disease and Emergency Analytics, Imperial College London. https://www.imperial.ac.uk/media/imperial-college/medicine/sph/ide/gidafellowships/Imperial-College-COVID19-Global-Impact-26-03-2020.pdf 


\section{POPULATION}

COUNCIL

Ideas. Evidence. Impact.

Wanqing, Z. (2020, March 2). Domestic Violence Cases Surge During COVID-19 Epidemic. Sixth Tone. https://www.sixthtone.com/news/1005253/domestic-violence-cases-surge-during-covid-19-epidemic

Wenham, C., Smith, J., \& Morgan, R. (2020). COVID-19: The gendered impacts of the outbreak. The Lancet, 395(10227), 846-848. https://doi.org/10.1016/S0140-6736(20)30526-2

Winter, S., Dzombo, M.N. \& Barchi, F. Exploring the complex relationship between women's sanitation practices and household diarrhea in the slums of Nairobi: a cross-sectional study. BMC Infect Dis 19, 242 (2019). https://doi.org/10.1186/s12879-019-3875-9

Wong, G., Liu, W., Liu, Y., Zhou, B., Bi, Y., \& Gao, G. F. (2015). MERS, SARS, and Ebola: The Role of SuperSpreaders in Infectious Disease. Cell Host \& Microbe, 18(4), 398-401. https://doi.org/10.1016/j.chom.2015.09.013

World Health Organization. (n.d.). Coronavirus Disease Situation Reports. Retrieved March 25, 2020, from https://www.who.int/emergencies/diseases/novel-coronavirus-2019/situation-reports 